\title{
Estimation of serum inflammatory cytokines( IL-4, IL 10 and IL 17) and total IgE concentrations in patients with bronchial asthma by ELISA technique.
}

\author{
Ihsan Edan Alsaimary ${ }^{1^{*}} \mid$ Falih Hmood Mezban ${ }^{2^{*}}$ \\ ${ }^{1}$ University of Basrah, College of \\ medicine, Department of \\ Microbiology, Basrah, Iraq \\ ${ }^{2}$ University of Basrah, College of \\ medicine, Department of \\ Microbiology, Basrah, Iraq

\begin{abstract}
This study aimed to determine the levels of immunomodulators by ELISA techniques. This study grouped asthmatic patients into three group of allergy modes according to concentration of total IgE measured by (ELISA) in which it was found that mode of allergy (very probable) IgE $>100$ IU. The immunological parameters included: measurement of IL 4,10 and 17 . The study showed a high significant elevation of various interleukin 4,10 and 17 . IL-4 record elevated in age group 3 in male (11.40) and group 5 male (18), IL-10 record elevated in age group 4 female (12.30).IL-17 record record elevated in age group 2 female and 3 male(12.90).

Keywords: ELISA, human bronchial asthma.interleukines
\end{abstract}

\section{1 | INTRODUCTION}

$\Lambda$ sthma is a complex respiratory disease in which genetic predisposition, environmental and immunological influences interfere with each other (Edwards, et al., 2012). It is considered one of the most prevalent chronic diseases, affecting approximately 300 million individuals (Masoli, et al., 2004) and causing an estimated 250,000 deaths each year (Bateman, et al., 2008). In addition, it is projected that by 2025 , the global asthma burden will rise by 100 million people due to a growing Westernized lifestyle and urbanization in developing countries (Masoli, et al., 2004). The 'hygiene theory' was originally attributed to an increase in the prevalence of allergic diseases, including asthma, indicating that decreased exposure to microbes during the first years of life plays a role in the development of allergic diseases (Strachan, 1989, 2000). While this theory is generally accepted, studies have shown that the increased incidence of asthma, rhinitis, or Neurodermitis does not completely account for decreased microbial exposure (Mallol, 2008; Brooks et al.,2013; Kramer et al., 2013). Asthma is a widespread illness globally and affects individuals of all ages, This condition usually occurs in infancy and is characterized by variable symptoms of wheeze, dyspnea, and chest tightness caused by air flow ob-

Supplementary information The online version of this article (https://doi.org/10.15520/jmrhs.v4i1.305 ) contains supplementary material, which is available to authorized users.

Corresponding Author: Ihsan Edan Alsaimary Hmood Mezban

University of Basrah, College of medicine, Department of Microbiology, Basrah, Iraq University of Basrah, College of medicine, Department of Microbiology, Basrah, Iraq 
ESTIMATION OF SERUM INFLAMMATORY CYTOKINES( IL-4, IL 10 AND IL 17) AND TOTAL IGE CONCENTRATIONS IN PATIENTS WITH BRONCHIAL ASTHMA BY ELISA TECHNIQUE

struction (fully reversible) (GINA, 2015; Bisgaard \& Bonnelykke,2010).

\section{2 | MATERIALS AND METHODS}

\section{Samples}

A total of (312) patients (149 males and 163 females) of various age groups were included in this Case -control study. The patient was examined, and diagnosed as asthma under supervision of the Physician.the study was carried out during a period from July 2018 to January 2020.

\section{The grouping of patient}

Male\& Female patients were divided into five groups according to (Falk, 1993; Herd,et al.,1996 ; Nishioka,1996 ; charman\&Williams,2002)

\section{Group 1: 1- 11 years}

\section{Group 2: 12 - 20 years}

Group 3: 21- 30 years

Group 4: 31 - 40 years

\section{Group 5: above 4o years}

\section{Control group}

A total of (204) healthy individual (81 males and 123 females) with out any features of asthma or any allergic to be compared with asthmatic patient in genetic and immunological studies.

TABLE 1: Reagent of human IgE Elisa Kit (ICL)

\begin{tabular}{|c|c|}
\hline Reagent & Quantity and characters \\
\hline Microtiter strip & $\begin{array}{l}12 \text { MIC 8-well snap-off strips,coated with } \\
\text { monoclonal Anti- } \mathrm{gE} E\end{array}$ \\
\hline Washing sol. Conc. & $\begin{array}{l}\text { 2*60 ml WS conc.for ca.120oml PBS Puffer } \\
\text { Tween } 20 \text { PH 6.5-7.0 }\end{array}$ \\
\hline Enzyme -antibody conjugate loox & $\begin{array}{l}\text { one vial containing } 22 \mathrm{ml} \text { of affinity purified } \\
\text { anti-human } \operatorname{IgE} \text { (goat)peroxidase -conjogate }\end{array}$ \\
\hline Chromogen-substrate sol. & $\begin{array}{c}\text { one vial containing } 13 \mathrm{ml} \text { of Substrate } \\
\text { Reagent } 3,3 ; 5,5- \\
\text { Tetramethylbenzidine(TMB) }\end{array}$ \\
\hline Stopping sol. & $\begin{array}{l}\text { one vial containing } 13 \mathrm{ml} \text { of } 0.5 \mathrm{~mol} / 1 \\
\text { sulfuric acid }\end{array}$ \\
\hline Adhesive strip & 2 Adhesive strip \\
\hline Human IgE calibrator & Six vials containing human IgE Calibrator \\
\hline
\end{tabular}

TABLE 2: IL-4 Elisa Kit with pre-coated plates(Blo LEGEND MAX Human.USA)

\begin{tabular}{|c|c|}
\hline Content Description & $\begin{array}{c}\text { Quantity(1 } \\
\text { plate) }\end{array}$ \\
\hline $\begin{array}{c}\text { Anti human IL 4 pre-coated 96-well Strip } \\
\text { Microplate }\end{array}$ & 1 Plate \\
\hline Human IL-4 Detection Antibody & 1 bottle \\
\hline Human IL -4 Standard & 1 Vial \\
\hline Matrix C (for serum and plasma sample only) & 1 bottle \\
\hline Avidin-HRP B & 1 bottle \\
\hline Assay buffer & 1 bottle \\
\hline Wash buffer (20 $x$ ) & 1 bottle \\
\hline Substrate solution $F$ & 1 bottle \\
\hline Stop solution & 1 bottle \\
\hline Plate sealers(4 sheets) & 1 pack \\
\hline
\end{tabular}

TABLE 3: IL-1o Elisa Kit with pre-coated plates (BIoLEGEND MAX Human.USA)

\begin{tabular}{|c|c|}
\hline Content Description & Quantity (1 plate) \\
\hline $\begin{array}{c}\text { Anti human IL 10 pre-coated 96-well Strip } \\
\text { Microplate }\end{array}$ & 1 Plate \\
\hline Human IL-10 Detection Antibody & 1 bottle \\
\hline Human IL-10 standard & 1 Vial \\
\hline Avidin-HRP A & 1 bottle \\
\hline Assay buffer & 1 bottle \\
\hline Wash buffer (20 x) & 1 bottle \\
\hline Substrate solution F & 1 bottle \\
\hline Stop solution & 1 bottle \\
\hline Plate sealers(4 sheets) & 1 pack \\
\hline
\end{tabular}

TABLE 4: IL-17 AElisa Kit with pre-coated plates(Blo LEGEND MAX Human. USA)

\begin{tabular}{|c|c|}
\hline Content Description & $\begin{array}{c}\text { Quantity(1 } \\
\text { plate) }\end{array}$ \\
\hline $\begin{array}{c}\text { Anti human IL17 A pre-c0ated 96-well Strip } \\
\text { Microplate }\end{array}$ & 1 Plate \\
\hline Human IL-17 A Detection Antibody & 1 bottle \\
\hline Human IL-17 A standard & 1 Vial \\
\hline Avidin-HRP D & 1 bottle \\
\hline Assay buffer & 1 bottle \\
\hline Wash buffer (20 $\mathrm{x}$ ) & 1 bottle \\
\hline Substrate solution F & 1 bottle \\
\hline Stop solution & 1 bottle \\
\hline Plate sealers (4 sheets) & 1 pack \\
\hline
\end{tabular}




\section{MEDICAL JOURNAL}

\section{3 | RESULTS}

\section{Total IgE}

Total concentration of IgE in Asthmatic patient sera of various age group illustrate in figure (1) Age groups were recorded the following concentration for male and female respectively $(95.4,184.4),(152.4,130.6)$,

$(102.0,271.2),(240.5,99.0)$

and $(206.3,258.1) \mathrm{IU} / \mathrm{ml}$ for age groups $1,2,3,4$ and 5 respectively there are a significant differences $(p<0.05)$ between concentration of various age groups and between male and female the concentra-tion of Total IgE in healthy person was 20-100 IU/ml (Allergy questionable) above 100 $\mathrm{IU} / \mathrm{ml}$ (Allergy very propable)



FIGURE 1: Total IgEconcentration in various age groups of Asthmatic patient $\mathrm{P}<0.05$

\section{IL-4}

The concentration of IL-4 in Asthmatic pa-tient sera in various age groups is illustrated in Fig.(3-4)for both male and female as follow. $(3.6,0.3),(2.5,6.2),(11.4,6.5),(9.3,8.1)$ an $\mathrm{d}(18,1.9) \mathrm{pg} / \mathrm{dl}$ for age groups 1,2,3,4 and 5 respectively. The standerd concentration of IL-4 in healthy person was(4.5-9.6)pg/dl there on astatically differences between a concentration of various age groups $(\mathrm{P}<0.05)$.

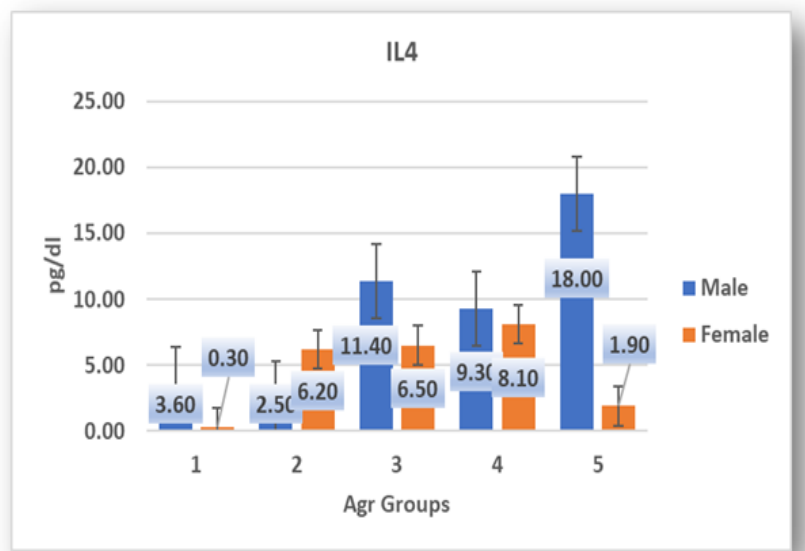

FIGURE 2: Concentration of IL-4 in various age groups ofAsthmatic patients $P<0.05$

\section{IL-10}

The concentration of IL-10 in asthmatic patient for each male and female in various groups is illustrated in figure (3) as follows: $(9.6,6.4),(0.8,11.5),(1.5,7.4),(10.4,12.3)$ and $(5.8,5.7) \mathrm{pg} / \mathrm{dl}$ for various age groups $1,2,3,4$ and 5 respectively the standard concentration for IL10 in healthy person were between (4.8-9.8) pg/dl there are significant differences between all studies concentration of IL-10 in age groups for both male and female $(\mathrm{P}<0.05)$

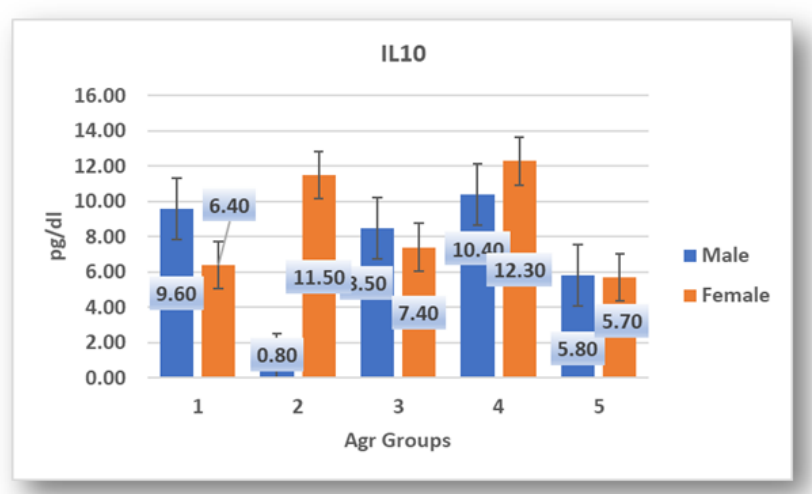

FIGURE 3: Concentrationof IL-10 in various age group of Asthmatic patients $\mathrm{P}<0.05$

\section{IL-17}

The concentration of IL-17 was studied in Asthmatic patient sera for male and female of various age groups and illustrate in Fig.(3-6) as follows: 
ESTIMATION OF SERUM INFLAMMATORY CYTOKINES( IL-4, IL 10 AND IL 17) AND TOTAL IGE CONCENTRATIONS IN PATIENTS WITH BRONCHIAL ASTHMA BY ELISA TECHNIQUE

$(9.6,6.7),(2.5,12.9),(12.9,5.5),(1.9,10.5) \quad$ and $(7.6,10.4) \mathrm{pg} / \mathrm{dl}$ for age groups $1,2,3,4$ and 5 respectively the standard value of IL-17 concentration was $(6.26-7.2) \mathrm{pg} / \mathrm{dl}$, There are statistical differences between concentration of IL-17 in both male and female of all studied age groups $(\mathrm{P}<0.05)$

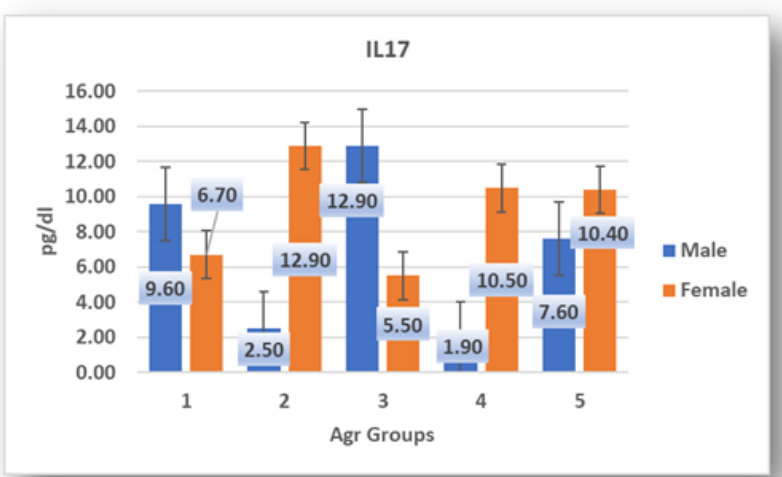

FIGURE 4: Concentration of IL-17 in various age groups of Asthmatic patient $\mathrm{P}<0.05$

\section{4 | DISCUSSION}

Interleukin 4 stimulates activated B-cell and Tcell proliferation. Also B cells differentiation and the class switching to IgE . Regarding IL-4 ,record elevated in age group 3 female (13.2 pg) and male (11.7 pg), group 4 female (12.1pg)and group 5 female $(11.3 \mathrm{pg})$ male $(10.2 \mathrm{pg})$ researcher believe IL-4 plays a crucial role in type $2 \mathrm{~T}$ helper responses and isotype class switching of B cells to IgE synthesis, and it has thus been suggested that IL-4 may have an important role in asthma pathogenesis IL-4 expression in this situation may simply reflect a surrogate marker of "Th2-type" T-cell activation, Our result confirmed by (Russell,R,2020;;Renauld,2001;jian et al.,2000;Kianmehr,M et al,.2019) .While other study not confirmed (Mazloomi,E,et al.2018;Saadat,S.et al.2020;Kianmehr,M. et al,2017).

IL-10 as an important risk gene for asthma (Nie W ,et al., 2012; Hyun M.et al.,2013) Regarding IL10,record elevated in age group 3 female $(13.4 \mathrm{pg})$ and group 4 male (10.2) and female (10.5) Our result confirmed by (Mahaki ,H.et al.,2020; Mokhtarizear,et al., 2020; Hajdu,Z.et al., 2018) other study not agreed(Mustafa,.2020;Ahmadi,M.et al.,2017).

IL-17 immunity has been associated with asthma exacerbations.( Favata, et al.2017; Mutters, et al.2017).Regarding IL-17 Majority in age group 3 male (12.90 pg) female (14.2 pg), researcher believe allergic asthma may be influenced by the IL-17 levels .Our result confirmed by (Kianmehr,M.et al.,2019;Guerra,E.2016;Saunders,S.P,et al.,2019).other result not confirmed (Saadat,S.et al.,2020; Chehimi,M.et al.,2017;Kianmehr.M.et al.,2017).

\section{5 | REFERENCES}

AL-SAIMARY IHSAN E. A STUDY OF ATOPIC DISEASES IN BASRAH GOVERNORATE. AFRICAN JOURNAL OF BIOTECHNOLOGY . 2009. VOL. 8 .NO.1 .

AL-SAIMARY IHSAN EDAN, SUNDIS S. BAKR, KHALIL E. AL-HAMDI. SERUM IMMUNOGLOBULIN AND COMPLEMENT COMPONENT LEVELS IN PATIENTS WITH ATOPIC DERMATITIS. ADVANCES IN BIORESEARCH . VOLUME 4 [1] MARCH2013: 111 - 115

AL-SAIMARY IHSAN EDAN, SUNDIS S. BAKR, KHALIL E. AL-HAMDI. STAPHYLOCOCCUS AUREUS AS A CAUSATIVE AGENT OF ATOPIC DERMATITIS/ ECZEMA SYNDROME (ADES ) AND ITS THERAPUTIC IMPLICATIONS. ADVANCES IN BIORESEARCH . VOLUME 4 [1] MARCH2013: 116 - 120 .

AL-SAIMARY, IHSAN EDAN, KHALIL E. ALHAMDI, SUNDIS S. BAKR .THE PREVALENCE OF ATOPIC ECZEMA / DERMATITIS SYNDROME (AEDS) IN BASRAH PROVIDENCE, IRAQ. ADVANCES IN BIORESEARCH . VOLUME 4 [1] MARCH 2013: 126 - 129.

Coates, A.L.;Wanger-Cockroft,D.W. and Culver,BH.(2017).Bronchoprovocation Testing Task Force. ERS technical standard on bronchial challenge testing: General considerations and performance of methacholine challenge tests. Eur. Respir. J.;49(5). 
Codispoti, C.D.; LeMasters, G.K.; Levin, L.; Reponen ,T.; Ryan, P.H.; Biagini Myers, J.M.; Codispoti,C. D.; LeMasters, G. K.; Villareal, M.; Burkle, J.; Evans, S. and Lockey, J. E. (2015). Traffic pollution is associated with early childhood aeroallergen sensitization. Ann Allergy Asthma Immunol.;114(2):126-33.

Colilla, S.; Nicolae, D.; Pluzhnikov, A.; Blumenthal, M. N.; Beaty, T. H.; Bleecker, E. R.; Lange, E. M.; Rich, S. S.; Meyers, D. A. and Ober, C. (2003). Evidence for gene-environment interactions in a linkage study of asthma and smoking exposure. Journal of Allergy and Clinical Immunology.; 111(4), 840-846.

Crameri, R., Garbani, M., Rhyner, C. and Huitema, C. (2014).Fungi: the neglected allergenic sources. Allergy.; 69(2): 176-185.

Cui, H.; Huang, J.; Lu, M.; Zhang, Q.; Qin, W.; Zhao, Y.; Lu, X.; Zhang, J.; Xi, Z. and Li, R. (2019).Antagonistic effect of vitamin $\mathrm{E}$ on nAl2O3-induced exacerbation of Th2 and Th17-mediated allergic asthma via oxidative stress. Environmental Pollution.; 252: 1519-1531.

Cullinan, P.; Harris, J.M.; Newman ,T.; Hole, A.M.; Jones, M.; Barnes, F. and Jolliffe, G.(2000).An outbreak of asthma in a modern detergent factory. Lancet.;356:1899-1900.

Czarnowicki, T.; Gonzalez, J.; Shemer, A.Czarnowicki, T.; ShMalajian, Dana.; Xu, H.; Zheng, X.; Khattri, S.; Gilleaudeau, P.; Sullivan-Whalen, M.; SuárezFariñas, M.(2015). Severe atopic dermatitis is characterized by selective expansion of circulating TH2/TC2 and TH22/TC22, but not TH17/TC17, cells within the skin-homing T-cell population. J. Allergy Clin. Immunol.;136(1):104-115.e7.

Daher, S.; Santos, L.M.; Sole, D.; De Lima, M.G.; Naspitz, C.K. and Musatti, C.C .(1995).Interleukin4 and soluble CD23 serum levels in asthmatic atopic children. J. Investig Allergol Clin. Immunol.;5:251254.

D’Amato, G., Stanziola, A., Sanduzzi, A., Liccardi, G., Salzillo, A., Vitale, C., Molino, A., Vatrella, A. and D'Amato, M.( 2014). Treating severe allergic asthma with anti-IgE monoclonal antibody (omalizumab): a review. Multidisciplinary respira- tory medicine, $9(1)$, p.23.

De Marco. R.; Locatelli, F.; Cerveri, I. Bugiani, M.; Marinoni, A. and Giammanco, G.(2002) Incidence and remission of asthma: A retrospective study on the natural history of asthma in Italy. J .Allergy Clin .Immunol.: 110(2): 228-235.

Harrington, L.E.; Mangan, P.R.and Weaver, C.T,(2006).Expanding the effector CD4 T-cell repertoire: the Th17 lineage.Curr Opin. Immunol.; 18:349-356.

Hamdy, R.M., Sobh, E. and Mohamed, S.A.A.(2015).Evaluation of pulmonary artery pressure and spirometry in chronic kidney disease children on regular hemodialysis. AL-AZHAR ASSIUT MEDICAL JOURNAL, 13(3).

Hashim, M.(2012).Obesity and Asthma Severity Among Adults Presenting to the Out Patient Clinic.Iraqi Academic Scientific Journal, 11(2):205210.

Hastie, A.;Moore, W.; Meyers, D.; Vestal, P.; Li, H.; Peters, S.and Bleecker, E.(2010). Analyses of asthma severity phenotypes and inflammatory proteins in subjects stratified by sputum granulocytes. Journal of Allergy and Clinical Immunology.;125(5).102836.

Heinrich, J. and Wichmann, H.E. (2004).Traffic related pollutants in Europe and their effect on allergic disease. Curr Opin Allergy Clin. Immunol.;4(5):3418.

Heinzerling, L., Mari, A., Bergmann, K.C., Bresciani, M., Burbach, G., Darsow, U., Durham, S., Fokkens, W., Gjomarkaj, M., Haahtela, T. and Bom, A.T.(2013). The skin prick test-European standards. Clinical and translational allergy, 3(1):1-10.

How to cite this article: I.E.A., F.H.M. Estimation of serum inflammatory cytokines( IL-4, IL 10 and IL 17) and total IgE concentrations in patients with bronchial asthma by ELISA technique. . Journal of Medical Research and Health Sciences. 2021;1151-1155. https://doi.org /10.15520/jmrhs.v4i1.305 